\title{
Combined Soft and Hard Tissue Peri-Implant Plastic Surgery Techniques to Enhance Implant Rehabilitation: A Case Report
}

\author{
Esra Baltacıoğlu ${ }^{1}$, Fatih Mehmet Korkmaz ${ }^{2}$, Nilsun Bağış ${ }^{3}$, Güven Aydın, Pınar Yuva ${ }^{4}$, Yavuz \\ Tolga Korkmaz \\ ${ }^{I}$ Department of Periodontology, Karadeniz Technical University, Faculty of Dentistry, Trabzon, Turkey \\ ${ }^{2}$ Department of Prosthodontics, Karadeniz Technical University, Faculty of Dentistry, Trabzon, Turkey \\ ${ }^{3}$ Department of Periodontology, Ankara University, Faculty of Dentistry, Ankara, Turkey \\ ${ }^{4}$ Beytepe Hospital, Hacettepe University, Ankara, Turkey \\ ${ }^{5}$ Department of Maxillofacial Surgery, Karadeniz Technical University, Faculty of Dentistry, Trabzon, Turkey \\ ${ }^{6}$ Department of Prosthodontics, Izmir Katip Celebi University, Faculty of Dentistry, Izmir, Turkey
}

\begin{abstract}
This case report presents an implant-aided prosthetic treatment in which peri-implant plastic surgery techniques were applied in combination to satisfactorily attain functional aesthetic expectations. Peri-implant plastic surgery enables the successful reconstruction and restoration of the balance between soft and hard tissues and allows the option of implant-aided fixed prosthetic rehabilitation.
\end{abstract}

Keywords: Augmentation, dental implant, peri-implant plastic surgery, soft and hard tissue.

\section{INTRODUCTION}

Dental implants are preferred over removable prostheses because they are convenient, as these prostheses are fixed [1]. For successful implants, soft and hard tissues should have adequate volume and quality and present a balanced unit for implant placement [1-8]. Peri-implant plastic surgery techniques have facilitated the development of healthy periimplant soft and hard tissue structures, thus providing more satisfactory functional and aesthetic implant results $[2-4,6$, 7].

Peri-implant plastic surgery is the adaptation of plastic surgery to implantology $[2-4,6,7]$. These techniques were initially presented as "soft tissue management/augmentation" for the treatment of soft tissue defects [2-4, 6]. Peri-implant plastic surgery has evolved into an expanded role and now includes the treatment of hard tissue defects. Currently, periimplant plastic surgery for hard tissue defects is considered a "bone enhancement/augmentation technique" [1-13].

Peri-implant soft tissue defects generally occur because of insufficient keratinized mucosa (KM) [3,4]. KM comprises dense, collagen-rich connective tissue, lined by a keratinizing epithelium. Peri-implant plastic surgery enables the creation of KM and the development of interimplant soft

*Address correspondence to this author at the Izmir Katip Celebi Universitesi, Aydınlık Evler Mahallesi, Cemil Meriç Caddesi, 6780 Sokak. No: 48, 35640-Çiğli / Izmir, Turkey; Tel: +90 532 6804656;

Fax: +90 462325 3017; E-mail: bbagis@yahoo.com tissue height in order to avoid food impaction, interimplant airflow, and speech problems [3].

Peri-implant hard tissue defects occur due to traumatic tooth extraction, advanced periodontal disease, and abscess formation [5]. These defects complicate or prevent ideal placement of an implant and create aesthetic problems $[1,9$, 10]. Application of bone augmentation in the defect area before implantation provides aesthetic and functional advantages and enables the optimal placement of implants $[1,9$, 10]. Bone augmentation techniques are useful in extraction socket defect grafting, horizontal ridge augmentation, vertical ridge augmentation, and sinus augmentation [1, 9-13]. Furthermore, autogenous bone grafts have been shown to be the most successful grafts because of lower infection rates versus other graft materials and their osteogenic and osteoinductive effects [1, 9-13].

When hard and soft tissue defects exist together, it presents the ideal opportunity to use combined peri-implant plastic surgical approaches [2-4]. In this study, we describe the techniques and clinical results of hard and soft tissue peri-implant plastic surgical procedures used in the before and after the implant period for our patient's oral rehabilitation.

\section{CASE PRESENTATION}

A 45-year-old woman presented to our clinic with missing left maxillary central and lateral teeth with an associated bone defect area. After initial examination, the left canine 


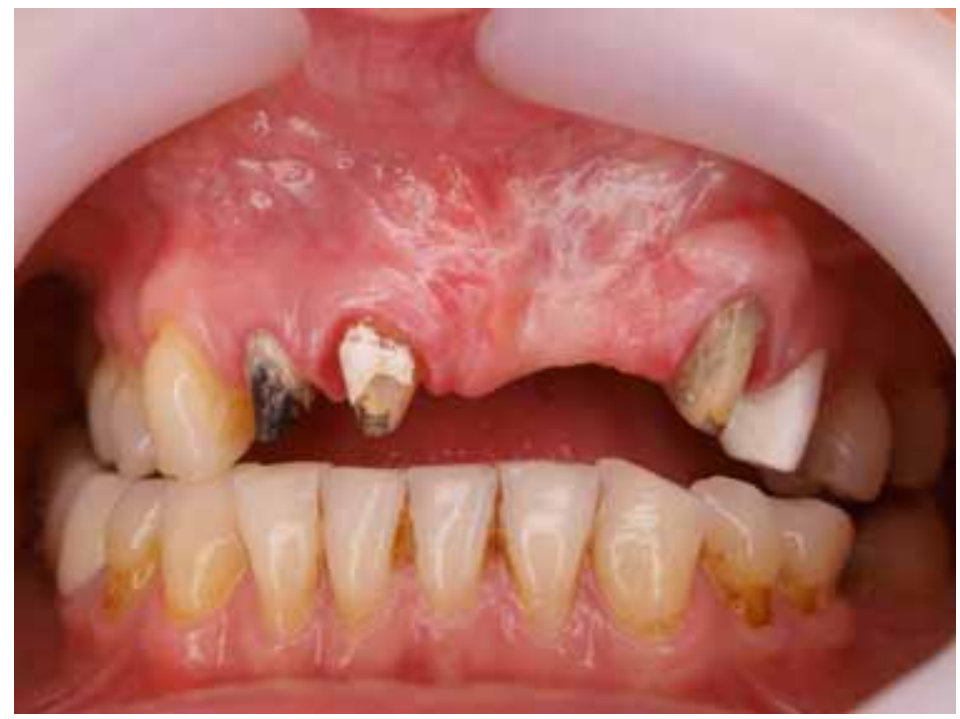

Fig. (1). Patient prior to treatment.

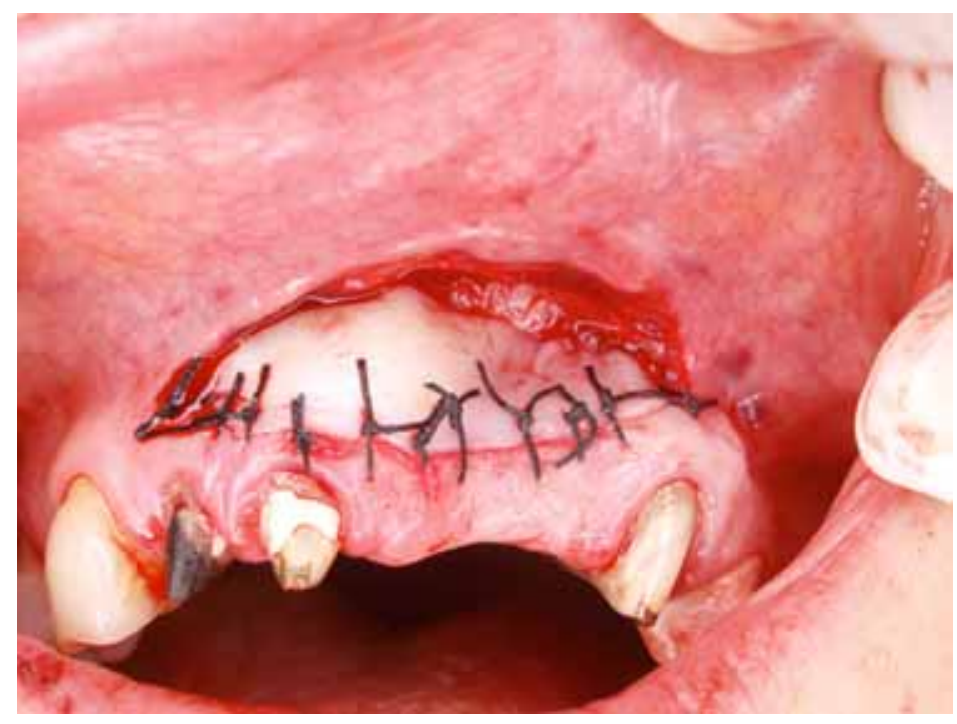

Fig. (2). FGG application of the anterior maxillary area, including the augmentation area.

tooth along with an associated endodontic-periodontal lesion was extracted (Fig. 1). The patient underwent clinical and radiographic (periapical and panoramic radiography and dental computed tomography) measurements. Because the potential implant site had a shallow vestibule due to heavy inflammation and a horizontal bone defect, it was felt that the patient would benefit from peri-implant plastic surgery. Right maxillary central and lateral teeth were extracted because of insufficient periodontal support. Pre-implant and post-implant plastic surgeries were planned.

\section{Pre-Implant Peri-Implant Procedures}

These surgical procedures were performed in two stages.

\section{KM Width Increase Via FGG}

To increase pre-implant KM width (KMW), we used the free gingival graft (FGG) technique (Fig. 2). The FGG was also used to cover the block bone graft completely to enhance healing. The block bone augmentation recipient site was prepared by making a horizontal incision from the mucogingival junction. The FGG was obtained from the hard palate. After three weeks, FGG vestibular depth was adequate and KM had formed.

\section{Monocortical Block Bone Augmentation}

Block bone augmentation was performed under local anesthesia three months after the FGG application (Fig. 3). Initially, a sulcular incision was made at the defect site. The exposed resorption site was measured in millimeters, and the dimensions of the block bone graft were determined according to these measurements. A horizontal incision was made from distal to the mandibular third molar, which was chosen as the donor site, to the ramus. The graft dimensions were marked with round burs, and the block graft was obtained using an osteotome. Subsequently, the graft was fixed to the defect site with a titanium screw. The flap was sutured to the graft site without tension. Postoperatively, the patient was prescribed amoxicillin/clavulanic acid $875 \mathrm{mg} / 125 \mathrm{mg}$ BID, an analgesic, and chlorhexidine mouthwash for 5 days. 


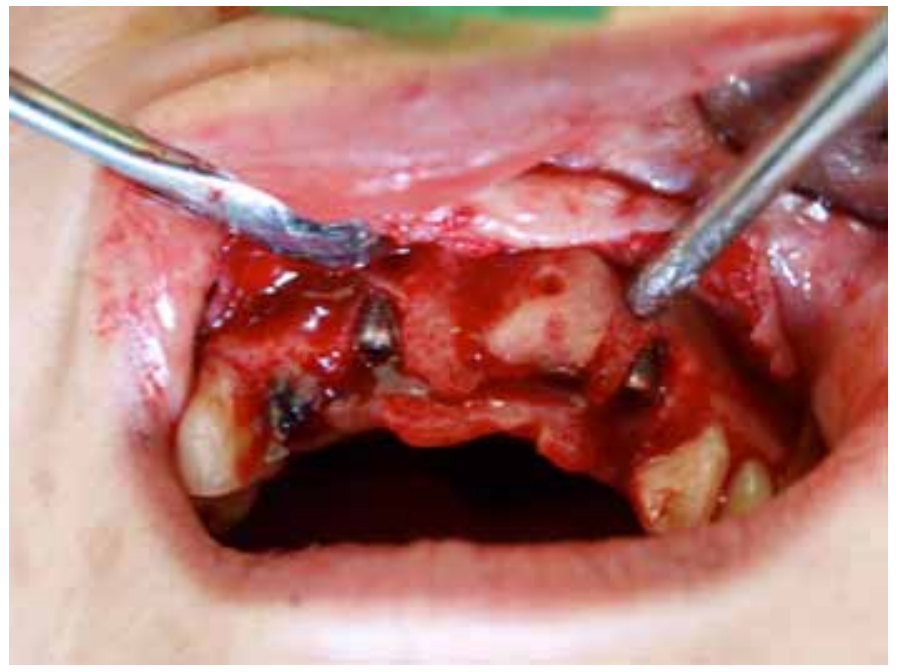

Fig. (3). Six months post-implant surgery and bone augmentation.

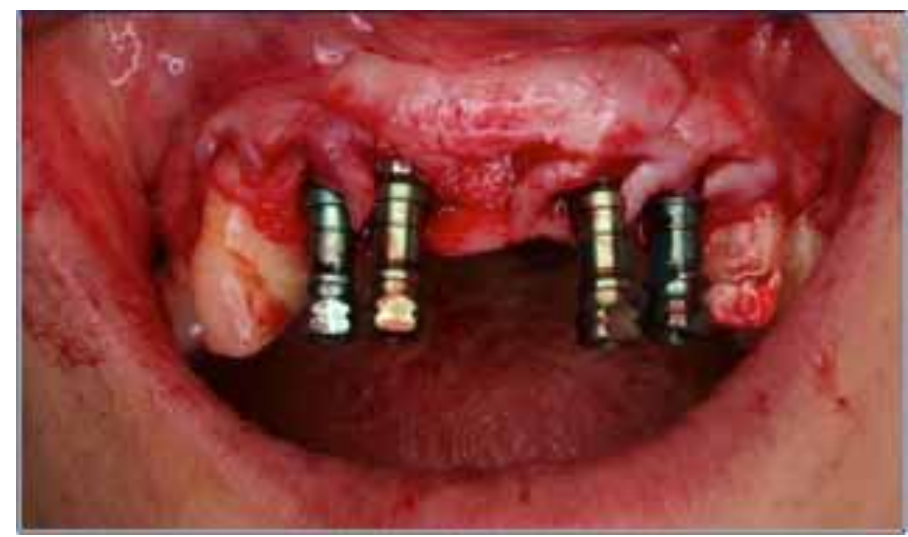

Fig. (4). Implant surgery and the papilla regeneration technique (second surgery). A full-thickness flap was elevated, and simultaneously, an immediate implantation was performed in the right central tooth area. Semilunar bevel incisions were made, recreating a scalloped shape similar to that of tissues around natural teeth (The rotation of the pedicles made it possible to close the space between the abutments).

\section{Implant Surgeries}

Implant therapy was performed in two stages. The first implant surgery was performed six months after the initial augmentation. The screw at the augmentation site was removed, and two dental implants (Tapered Screw-Vent, diameter: 4.1, and length: $10 \mathrm{~mm}$; Zimmer Dental, Carlsbad, CA, USA), were placed at the site. The central tooth in the right maxillary area was extracted because of insufficient periodontal support and the possible risk of prosthetic failure, even in the short term. The area surrounding the implant was supported with a bone graft and a collagen membrane. A second implant surgery was performed four months after the first implant surgery, during which time the patient had used fixed provisional bridges.

\section{Post-Implant Peri-Implant Procedures}

\section{Papilla Regeneration Technique}

At the time of the second implant surgery, the provisional bridge was removed, and the initial implants were exposed. The maxillary right lateral tooth was extracted, and papilla regeneration was performed. A full-thickness flap was elevated and reflected labially. The healing abutments held the flap in place. Semilunar bevel incisions were made, recreating a scalloped shape similar to that of tissues around natural teeth. The tissue was rotated towards the palate to create a papilla between the implant and the tooth. The flap pedicles filled the interimplant space. Sutures (5.0-trofilen monofilament; polyvinylidene fluoride) were used to secure the tissues. This technique was done not only around implants placed four months previously, but also immediately after for the additional implants placed that day (Fig. 4, 5).

\section{Prosthetic Restorations}

Temporary prosthetic restorations were performed 2 months after the papilla regeneration technique; subsequently, there was no observable pathological tissue reaction at the socket site. The alveolar ridge was nearly flat. For an aesthetic view, the provisional bridge was modified on the maxillary left central tooth area to form papilla on both sides of the tooth. The pontic area on the left central tooth was carved on the cast, and provisional restoration was formed 


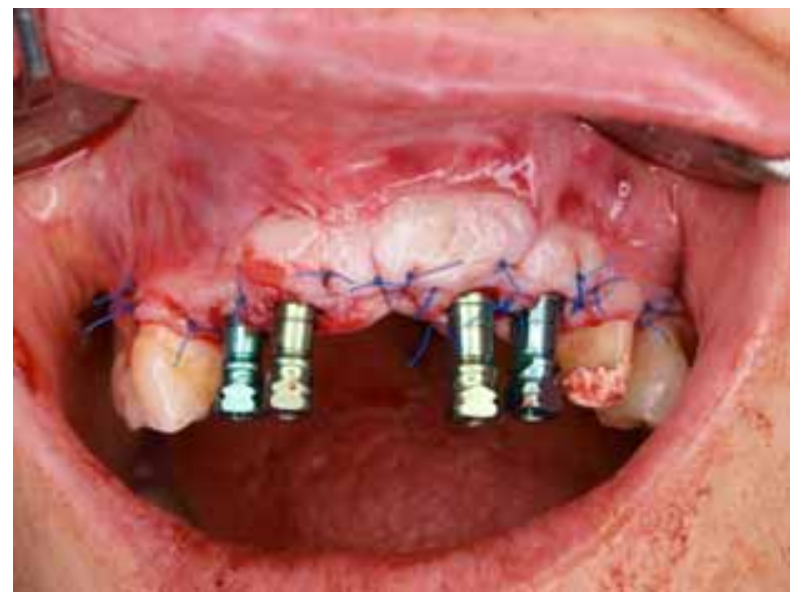

Fig. (5). Suturing of the flap.

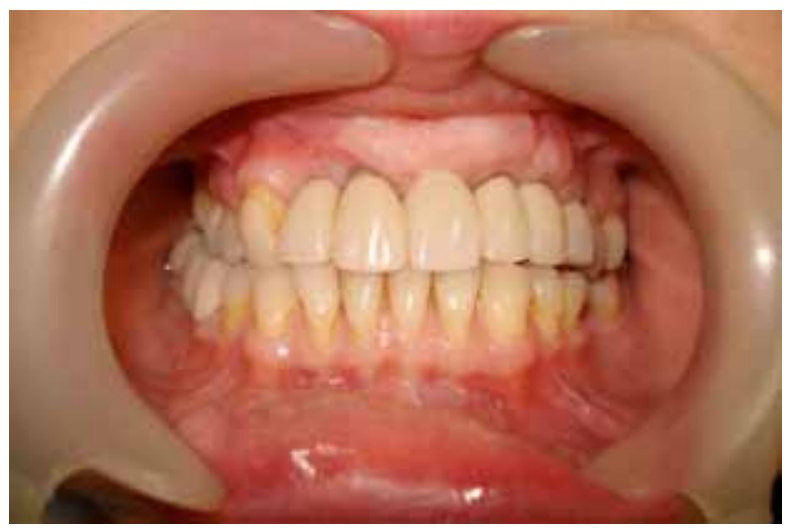

Fig. (6). Provisional restorations with over contouring in the central tooth area.

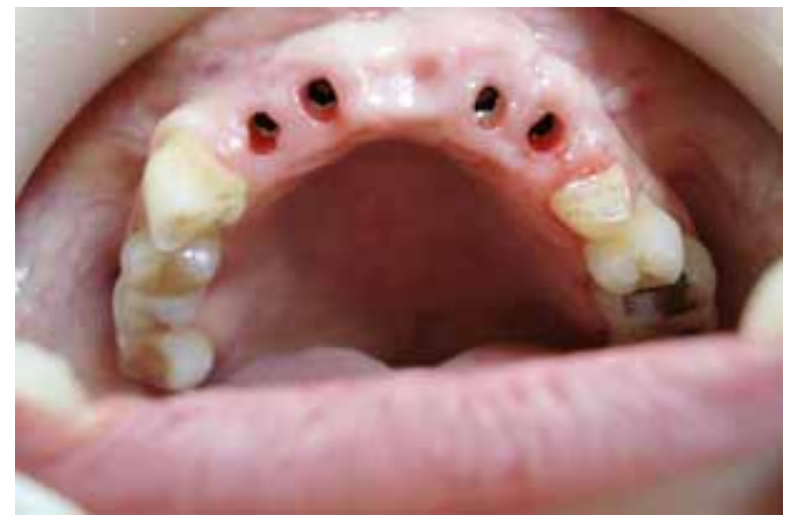

Fig. (7). Papilla formation in edentulous area.

with over contouring. To prevent infection, the pontic was polished carefully, and restoration was temporarily luted (Fig. 6). Follow-up visits were continued until we were satisfied with the appearance of the papilla and alveolar ridge at the end of the fourth month (Fig. 7). At that time, definitive bridges were fabricated using metal-ceramic restorations. At the 24-month follow-up, the patient had no functional, psychological, aesthetic, or phonetic problems (Fig. 8).

\section{DISCUSSION}

The functional and aesthetic success of dental implant procedures depends on the balance between soft and hard tissue structures [2-4]. Therefore, soft and hard tissues are best prepared for ideal implant positioning by the use of periimplant plastic surgery techniques [2-4]. Because there is no consensus on the ideal peri-implant plastic surgery approach, the decision regarding which techniques to apply depends primarily on the clinician's choice [4].

The patient presented in our report had a severe horizontal defect and a shallow vestibular depth resulting from previous infection at the anterior maxillary site. This made implant-aided fixed prosthetic treatment challenging. Implant surgery was performed in several stages, and aesthetic. expectations were managed using fixed temporary bridges.

Peri-implant plastic surgery was performed in two stages: pre-implantation and post-implantation. The aim of the pre- 


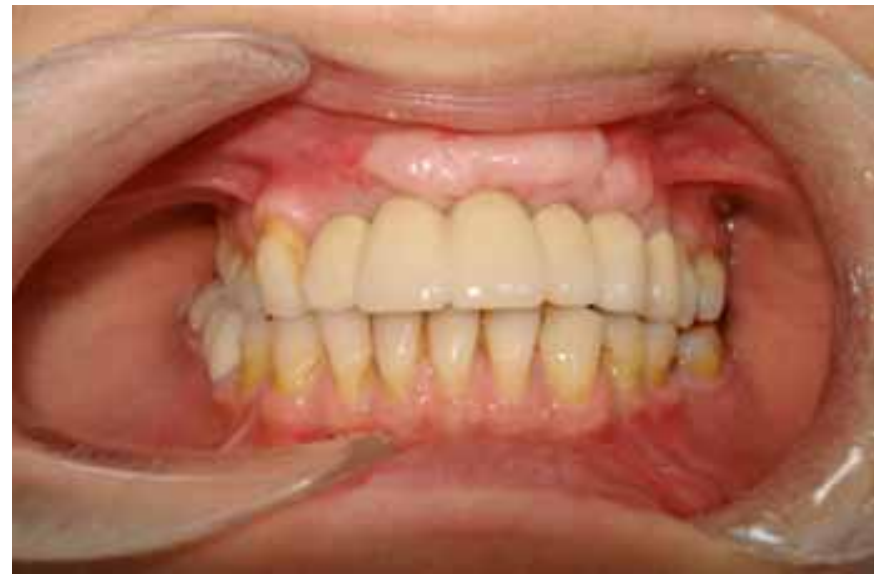

Fig. (8). Clinical appearance after prosthetic rehabilitation was completed.

implant procedures was to create sufficient bone and $\mathrm{KM}$ in preparation for the implants. Initially, KMW increased via the FGG. A FGG was also used to cover the block bone graft completely and to enhance healing. Thus, the implant site was prepared for augmentation by application of the FGG graft. This method is an alternative to the "controlled tissue expansion" technique [14]. Increasing the KMW benefited peri-implant tissue health.

During the second stage of pre-implant plastic surgery, monocortical block bone augmentation was used to obtain bone of sufficient volume and quality. In defects in which horizontal ridge formation is too severe, implant placement may be impossible [1, 9, 10, 15]. Several methods have been used to maintain horizontal ridge augmentation [1, $9,10,15]$. A bone block graft is the preferred method for many types of augmentation procedures because it secures a source of osteogenic cells and provides a rigid structure for mechanical support $[1,9,15,16]$. Recent studies have shown that block bone grafts from the mandibular ramus site lead to successful bone reconstruction in the maxillary alveolar ridge $[1,16]$. However, the slow revascularization and remodeling processes of mandibular bone blocks requires waiting at least four months after graft healing before implant insertion $[17,18]$. We detected no necrosis in our case after the augmentation, during the six month wait before performing the implant.

There is no consensus regarding the timing of periimplant plastic surgery. Soft tissue enhancements have been performed before, during, or after implantation surgery for the prevention or treatment of peri-implantitis $[2,4,6,19$, 20]. In our case, soft tissue augmentation using the FGG was performed several months before the first implantation procedure, and papilla regeneration was performed immediately after the second implantation.

Using this technique, papilla regeneration and tight fibrous tissue attachments were achieved simultaneously. Two months after the papilla regeneration procedure, temporary prosthetic restorations were fashioned, and permanent restorations were made after 4 months.

In conclusion, we present a case of an implant-aided prosthetic treatment in which peri-implant plastic surgery techniques were applied in combination to satisfactorily at- tain functional aesthetic expectations. Peri-implant plastic surgery enables the successful reconstruction and restoration of the balance between soft and hard tissues and allows the option of implant-aided fixed prosthetic rehabilitation. Moreover, in cases that require long-term treatment planning, as in our case, a multidisciplinary approach is most desirable.

\section{CONFLICT OF INTEREST}

The authors confirm that this article content has no conflict of interest.

\section{ACKNOWLEDGEMENTS}

Declared none.

\section{REFERENCES}

[1] McAllister BS, Haghighat K. Bone augmentation techniques. J Periodontol 2007; 78: 377-96.

[2] Kazor CE, Al-Shammari K, Sarment DP, Misch CE, Wang HL. Implant plastic surgery: a review and rationale. J Oral Implantol 2004; 30: 240-54.

[3] Palacci P, Nowzari H. Soft tissue enhancement around dental implants. Periodontol 2000 2008; 47: 113-32.

[4] Baltacıoğlu E, Bagış B, Korkmaz FM, Aydın G, Yuva P, Korkmaz YT. Peri-implant plastic surgical approaches to increasing keratinised mucosa width: Which to use and when? J Oral Implantol 2013. [epub ahead of print]

[5] Baltacıoğlu E, Pampu A, Bağıș B, Saraç Ö Ustaömer S, Dannan A Oral implant application following free gingival graft and horizontal ridge augmentation: a case report. İnternet J Dental Sci 2009; 9: 2.

[6] Cairo F, Pagliaro U, Nieri M. Soft tissue management at implant sites. J Clin Periodontol 2008; 35(8 Suppl): 163-7.

[7] Wennström JL, Derks J. Is there a need for keratinized mucosa around implants to maintain health and tissue stability? Clin Oral Implants Res 2012; 23 (Suppl 6): 136-46.

[8] Jovanovic SA. Bone rehabilitation to achieve optimal aesthetics. Pract Periodontics Aesthet Dent 1997; 9: 41-51.

[9] Donos N, Mardas N, Chadha V. Clinical outcomes of implants following lateral bone augmentation: systematic assessment of available options (barrier membranes, bone grafts, split osteotomy). J Clin Periodontol 2008; 35 (Suppl 8): 173-202.

[10] Takei HH, Azzi R, Han T. Clinical Periodontology: Localized bone augmentation and implant site development. In: Newmann MG, Takei HH, Klokkevold PR, Carranza FA, Eds. Philadelphia: 2006; p. 1133-47. 
[11] Laino L, Lezzi G, Piatelli A, Lo Muzio L, Cicciu M. Vertical ridge augmentation of the atrophic posterior mandible with sandwich technique: bone block from the chin area versus corticocancellous bone block allograft: clinical and histological prospective randomized controlled study. Biomed Res Int 2014; 2014: 982104.

[12] Herford AS, Lu M, Akin L, Cicciu M. Evaluation of a porcine matrix with and without platelet-derived growth factor for bone graft coverage in pigs. Int $\mathbf{J}$ Oral Maxillofac Implants 2012; 27:1351-8

[13] Cicciu M, Scott A, Cicciu D, Tandon R, Maiorana C. Recombinant human bone morphogenetic protein-2 promote and stabilize hard and soft tissue healing for large mandibular new bone reconstruction defects. J Craniofac Surg 2014; 25: 860-2.

[14] Bahat O, Koplin LM. Pantographic lip expansion and bone grafting for ridge augmentation. Int J Periodont Restorat Dent 1989; 9: 34453.

[15] Esposito M, Grusovin MG, Felice P, Karatzopoulos G, Worthington HV, Coulthard P. Interventions for replacing missing teeth: horizontal and vertical bone augmentation techniques for dental implant treatment. Cochrane Database Syst Rev 2009; 7 : CD003607.

[16] Pikos MA. Block autografts for localized ridge augmentation: Part II. The posterior mandible. Implant Dent 2000; 9: 67-75.

[17] Aalam AA, Nowzari H. Mandibular cortical bone grafts part 1: anatomy, healing process, and influencing factors. Compend Contin Educ Dent 2007; 28: 206-12.

[18] Felice P, Iezzi G, Giuseppe Lizio G, Piattelli A, Marchetti C. Reconstruction of atrophied posterior mandible with inlay technique and mandibular ramus block graft for implant prosthetic rehabilitation. J Oral Maxillofac Surg 2009; 67: 372-80.

[19] Thoma DS, Benić GI, Zwahlen M, Hämmerle CH, Jung RE. A systematic review assessing soft tissue augmentation techniques. Clin Oral Implants Res 2009; 20 (Suppl 4): 146-65.

[20] Esposito M, Maghaireh H, Grusovin MG, Ziounas I, Worthington HV. Soft tissue management for dental implants: what are the most effective techniques? A Cochrane systematic review. Eur J Oral Implantol 2012; 5: 221-38.

Received: July 25, 2015

Revised: September 30, 2014

Accepted: October 01, 2014

(C) Baltacioğlu et al.; Licensee Bentham Open.

This is an open access article licensed under the terms of the Creative Commons Attribution Non-Commercial License (http://creativecommons.org/licenses/by-nc/3.0/) which permits unrestricted, non-commercial use, distribution and reproduction in any medium, provided the work is properly cited. 